\title{
RESPIRATORY MUSCLE IMPAIRMENT EVALUATED WITH MEP/MIP RATIO IN CHILDREN AND ADOLESCENTS WITH CHRONIC RESPIRATORY DISEASE
} Fraqueza muscular respiratória avaliada por meio da relação
PEmax/PImax em crianças com doença respiratória crônica

\author{
Iván Rodríguez-Núñez ${ }^{a, *}$ (D), Gerardo Torres ${ }^{b}$ (D), Soledad Luarte-Martineza (D), \\ Carlos Manterolac ${ }^{c}$ (D), Daniel Zenteno ${ }^{a}$ (D)
}

\section{ABSTRACT}

Objective: To evaluate the strength of respiratory muscles and to compare maximum inspiratory (MIP) and expiratory (MEP) pressure and MEP/MIP ratio between patients with chronic respiratory diseases and healthy individuals.

Methods: Case-control study. Individuals with neuromuscular disease and post-infectious bronchiolitis obliterans were considered. In addition, they were also matched according to anthropometric and demographic characteristics with healthy children and adolescents. MIP, MEP in the three groups, and pulmonary function only in patients with chronic respiratory diseases were recorded.

Results: A total of 52 subjects with CRD (25 with neuromuscular disease, and 27 with post-infectious bronchiolitis obliterans) and 85 healthy individuals were included, with an average age of $11.3 \pm 2.1$ years. Patients with neuromuscular disease and post-infectious bronchiolitis obliterans presented lower MIP and MEP when compared with healthy individuals, although MEP/MIP ratio was lower in patients with neuromuscular disease $(0.87 \pm 0.3)$ and higher in patients with post-infectious bronchiolitis obliterans (1.1 \pm 0.3 ) compared to the healthy group (0.97 \pm 0.2 ). Only in patients with neuromuscular disease a negative correlation was observed between MEP/MIP ratio and age ( $r=-0.50 ; p=0.01$ ). Conclusions: Differences in the pattern of muscular weakness between patients with chronic respiratory diseases were observed. In patients with neuromuscular disease, a decrease in the MEP/MIP ratio depending on MIP was verified; and in those patients with post-infectious bronchiolitis obliterans, an increase in the MEP/MIP ratio depending on MIP was also observed.

Keywords: Muscle strength; Respiratory muscles; Muscle fatigue; Muscle weakness; Neuromuscular disease; Bronchiolitis obliterans.
RESUMO

Objetivo: Avaliar a força dos músculos respiratórios e comparar a relação entre a pressão expiratória máxima (PEmáx) e a pressão inspiratória máxima (PImáx) em pacientes com doença respiratória crônica (DRC) e crianças saudáveis.

Métodos: Estudo caso-controle. Foram selecionados indivíduos com doença neuromuscular e bronquiolite obliterante pós-infecciosa. Ademais, os grupos foram pareados com crianças e adolescentes saudáveis, considerando características antropométricas e demográficas. Foram registradas a PImáx e a PEmáx nos três grupos e a função pulmonar apenas em pacientes com doença respiratória crônica.

Resultados: Foram incluídos 52 indivíduos com DRC (25 com doença neuromuscular e 27 com bronquiolite obliterante pós-infecciosa)

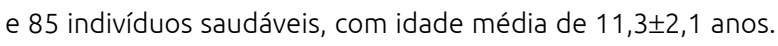
Pacientes com doença neuromuscular e bronquiolite obliterante pós-infecciosa apresentaram menor PImáx e PEmáx em comparação aos indivíduos saudáveis, embora a relação PEmáx/PImáx tenha sido menor nos pacientes com doença neuromuscular $(0,87 \pm 0,3)$ e maior nos pacientes com bronquiolite obliterante pós-infecciosa $(1,1 \pm 0,3)$ em comparação ao grupo saudável $(0,97 \pm 0,2)$. Somente em pacientes com doença neuromuscular foi observada uma correlação negativa entre a razão PEmáx/PImáx e a idade $(r=-0,50 ; p=0,01)$.

Conclusões: Foram observadas diferenças no padrão de fraqueza muscular em pacientes com doença respiratória crônica. Nos pacientes com doença neuromuscular, verificou-se diminuição na relação PEmáx/PImáx dependendo da PImáx; em pacientes com bronquiolite obliterante pós-infecciosa, foi observado aumento na relação dependendo da PImáx.

Palavras-chave: Força muscular; Músculos respiratórios; Fadiga muscular; Fraqueza muscular; Doença neuromuscular; Bronquiolite obliterante.

*Corresponding author. E-mail: ivanrodriguez@udec.cl (I. Rodríguez N.).

aniversidad de Concepción, Chile.

bDr. Guillermo Grant Benavente Hospital, Concepción, Chile.

¿Universidad de La Frontera, Chile.

Received on January 16, 2020; approved on April 23, 2020; available online on December 15, 2020. 


\section{INTRODUCTION}

The functional deterioration of respiratory muscles is considered a frequent complication in chronic respiratory diseases (CRD). ${ }^{1-3}$ Several studies have revealed the existence of a significant drop in strength and resistance of inspiratory and expiratory muscles in children and adolescents with chronic pulmonary damage and neuromuscular diseases (NMD), ${ }^{4-7}$ which promotes the development of hypoventilation, microatelectasis, and deterioration of cough mechanisms, altering their prognosis. ${ }^{4,8,9}$

One of the most prevalent CRD in our pediatric population is the post-infectious bronchiolitis obliterans (PIBO), which occurs secondarily to a pulmonary infection during childhood. ${ }^{10,11}$ Among its complications, a severe functional deterioration secondary to pulmonary damage is highlighted. ${ }^{12,13}$ However, the magnitude of respiratory muscular deterioration has not been explored in this group of patients.

In the clinical context, the evaluation of the strength of respiratory muscles is performed with measurements of maximum inspiratory pressure (MIP) and maximum expiratory pressure (MEP) exerted through the mouth. ${ }^{14,15}$ This evaluation method has been validated in adults and children, and it has been used both for evaluating and monitoring patients with CRD. ${ }^{16-18}$ For this purpose, the absolute value of MIP and MEP expressed in $\mathrm{cmH}_{2} \mathrm{O}$ is considered, as well as its percentage value relative to a standard value calculated from reference equations, in which age, gender and anthropomorphic characteristics of the target population are often considered as predictive variables. ${ }^{15,19}$

Despite the above, independent values of MIP and MEP are not useful to analyze the imbalance between the magnitude of inspiratory and expiratory strength in a specific individual. Consequently, it has recently been shown that MEP/MIP ratio could be a suitable and straight forward parameter for establishing with certainty the strength loss of respiratory muscles in healthy adults with paralysis of the phrenic nerve and progressive NMD. ${ }^{20,21}$

Until now, respiratory muscle balance in healthy children is unknown, as well as the pattern of muscular weakness in CRDs patients. Additionally, there is no evidence of respiratory muscle deterioration and variation in the MEP/MIP ratio in patients with PIBO. Therefore, the objective of the present study was to evaluate the strength of inspiratory and expiratory muscles in healthy children and adolescents, affected by NMD and PIBO, as well as to calculate MEP/MIP ratio and compare the value obtained between the study groups. We hypothesize that both children with NMD and PIBO have lower respiratory muscle strength when compared to healthy subjects, and present significant differences in the pattern of muscular weakness measured with the MEP/MIP ratio.

\section{METHOD}

In this case-control study, the records of MIP, MEP, and pulmonary function of children and adolescents admitted in the Infant Pulmonary Rehabilitation Program of Dr. Guillermo Grant Benavente Hospital of Concepción, Chile, between 2011 and 2016, were selected. The existence of cognitive deficit and the presence of an acute clinical disorder that would have altered the basal state of patients within four weeks before the pulmonary function tests were considered as exclusion criteria.

Besides that, healthy individuals belonging to four public schools in Concepción City were invited to participate in the study. Members of this group were matched by age $( \pm 1$ year old), gender (same gender), weight, and height $( \pm 5 \%)$ with patients with NMD and PIBO. The existence of obesity, cardiorespiratory or chronic neuromuscular disease, and the presence of any acute pathology during the four weeks before measuring variables were considered as exclusion criteria. Eligibility criteria were verified with a checklist completed by parents.

Parents or legal tutors of each participant in the study signed an informed consent form, and children younger than 12 signed an informed assent. The study was approved by the Scientific Ethical Committee of Dr. Guillermo Grant Benavente Hospital of Concepción.

Sample size was estimated considering a $5 \%$ of type I risk error, the statistical power of $99 \%$, a standard deviation of $20 \mathrm{~cm}$ $\mathrm{H}_{2} \mathrm{O}$, and a minimum clinically significant difference in the MIP of $20 \mathrm{~cm} \mathrm{H} \mathrm{H}_{2} \mathrm{O}$ between healthy individuals and those affected with CRD. Moreover, a 1:3 ratio between patients with CRD and healthy individuals was considered. Thus, a minimum of 25 individuals in NMD and PIBO groups, as well as 75 individuals in the control group were estimated to perform the study.

In the three groups under study, variables such as age, gender, height, weight, MIP, and MEP were recorded. Both weight and height were determined by an analogous scale and a metric tape. On the other hand, pulmonary function parameters were only recorded from patients with NMD and PIBO.

Pulmonary function was determined by spirometry, which was evaluated according to the protocol established by the European Respiratory Society and the American Thoracic Society (ERS/ATS). ${ }^{22}$ The parameters considered in the study were forced expiratory volume at first second $\left(\mathrm{FEV}_{1}\right)$, forced vital capacity (FVC), $\mathrm{FEV}_{1} / \mathrm{FVC}$ index, and forced expiratory flow between $25 \%$ and $75 \%$ of $\mathrm{FVC}\left(\mathrm{FEF}_{25-75}{ }^{\circ}\right)$. Results were expressed in absolute values and percentages of predictive value, according to Knudson et al. ${ }^{23}$ Pulmonary function was determined with a Microlab ML3500 spirometer (Micro Medical Ltd, Rochester, England).

The strength of respiratory muscles was determined by the maximum inspiratory pressure (MIP), measured with a maximum inspiratory effort maintained for at least one second from 
the residual volume. On the other hand, the maximum expiratory pressure (MEP) was measured with the maximum respiratory effort maintained for at least one second from the total pulmonary capacity. ${ }^{14}$ The best MIP and MEP values from three acceptable and reproducible attempts was recorded. Values obtained were expressed in absolute values $\left(\mathrm{cm} \mathrm{H}_{2} \mathrm{O}\right)$ and percentages according to Chilean predictive values published by Contreras et al. ${ }^{24}$

The tools used to measure muscle strength were a digital pressure meter (MicroRPM; Vyaire Medical Inc., Mettawa, IL, USA) and an aneroid pressure gauge (Vacuum/Pressure Gauge NS120-TRS; Instrumentation Industries, Inc. Bethel Park, USA) calibrated in centimeters of water ( 0 to -120 and 0 to $+120 \mathrm{~cm} \mathrm{H}_{2} \mathrm{O}$ ). Equipment showed to be valid and reliable to determine the strength of inspiratory and expiratory muscles. ${ }^{24,25}$

Exploratory analysis of data was performed with normality evaluation using the Shapiro Wilk test. Subsequently, descriptive statistic was performed with the calculation of average and standard deviation for quantitative variables, and percentage for qualitative variables. Chi-square was used to evaluate the difference of proportions of qualitative variables, Student's t-test for independent samples to compare parameters of pulmonary function between groups of patients with CRD, and Student's t-test for related samples to compare MEP/MIP ratio with the $\% \mathrm{MEP} / \% \mathrm{MIP}$, for each study group. On the other hand, Levene's test was used to evaluate heterogeneity of variances. Therefore, in order to compare quantitative variables between the three groups under study when there was no statistical significance in heterogeneity of variances, one-way ANOVA and Scheffé post hoc test were used. When there was heterogeneity of variances, the Kruskal Wallis test was used. Finally, Pearson's correlation coefficient was used to determine the correlation between the MEP/MIP ratio (and \%MEP/\%MIP ratio) with both parameters of respiratory muscle strength (MIP and MEP) and with the age of participants. The analysis was performed by using the statistic software MedCalc, version 17.4 (MedCalc Software bvba, Ostend, Belgium), and a value of $\mathrm{p}<0.05$ was considered as statistically significant.

\section{RESULTS}

The study included 52 individuals with CRD and 85 healthy individuals. Of the patients with CRD, 25 presented NMD, and 27, PIBO. Flowchart of recruitment of study subjects is shown in Figure 1. No significant differences were observed between groups as to age, gender, and anthropometric variables (Table 1).

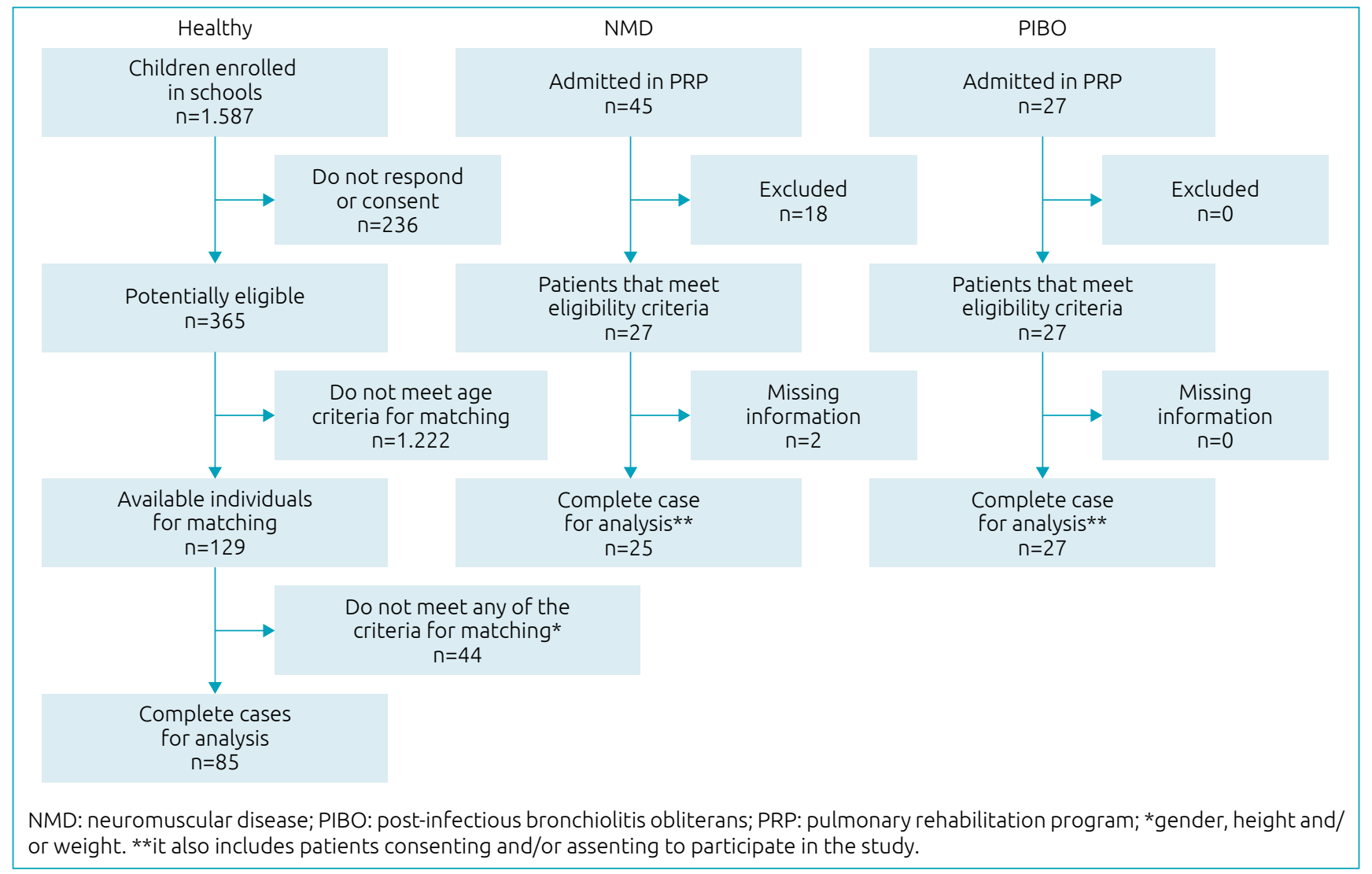

Figure 1 Flowchart of recruitment of study subjects. 
The group of patients with NMD consisted of patients with Duchenne muscular dystrophy $(\mathrm{n}=13 ; 52.0 \%)$, congenital myopathy ( $\mathrm{n}=4 ; 16.0 \%)$, Type II spinal atrophy $(\mathrm{n}=3$; $12.0 \%)$, Becker muscular dystrophy $(\mathrm{n}=1 ; 4.0 \%)$, fascioscapulohumeral dystrophy $(\mathrm{n}=1 ; 4.0 \%)$, and Bethlem myopathy $(\mathrm{n}=1 ; 4.0 \%)$.

Regarding pulmonary function, $\mathrm{FEV}_{1}(\%), \mathrm{FEF}_{25-75}$ (absolute value and percentage) and FEV1/FVC ratio were lower in patients with BIPO, compared to patients with NMD $(\mathrm{p}<0.05)$. Additionally, the existence of a restrictive ventilatory pattern was observed in children with NMD, and an obstructive ventilatory pattern, in children with PIBO (Table 2).

Results of respiratory muscle strength and MEP/MIP ratio are shown in Table 3. Both patients with NMD and PIBO presented MIP and MEP values lower than those of healthy individuals. On the other hand, patients with NMD presented lower absolute values in MIP, MEP, and \%MEP compared to patients with PIBO. Additionally, a positive correlation was observed between MIP and MEP in healthy $(r=0.60 ; p<0.001)$, NMD $(r=0.58 ; p=0.021)$, and PIBO $(r=0.60 ; p=0.001)$.

Table 1 General characteristics of the study groups.

\begin{tabular}{l|c|c|c|c} 
& $\begin{array}{c}\text { Healthy } \\
(\mathbf{n}=85)\end{array}$ & $\begin{array}{c}\text { NMD } \\
(\mathbf{n}=25)\end{array}$ & $\begin{array}{c}\text { PIBO } \\
(\mathbf{n}=27)\end{array}$ & p-value* \\
\hline $\begin{array}{l}\text { Age } \\
\text { (years old) }\end{array}$ & $11.1 \pm 1.6$ & $11.4 \pm 2.9$ & $11.7 \pm 2.8$ & $0.384 *$ \\
\hline $\begin{array}{l}\text { Gender } \\
(\mathrm{M} / \mathrm{F})\end{array}$ & $47 / 38$ & $18 / 7$ & $19 / 8$ & $0.179 * *$ \\
\hline Weight $(\mathrm{kg})$ & $47.5 \pm 13.1$ & $46.5 \pm 13.2$ & $44.1 \pm 11.4$ & $0.483 *$ \\
\hline Height $(\mathrm{cm})$ & $149.4 \pm 10.5$ & $145.5 \pm 9.5$ & $151.3 \pm 11.4$ & $0.300 *$ \\
\hline
\end{tabular}

NMD: neuromuscular disease; PIBO: post-infectious bronchiolitis obliterans; M: male; F: female. *One-way ANOVA; **chi-square test was used.
Regarding the MEP/MIP ratio, there was a significant difference between the absolute and relative values in the three groups $(\mathrm{p}<0.001)$. In addition to that, statistically significant differences were observed between groups in both MEP/MIP ratio and in the \%MEP/\%MIP ratio. Post-hoc analysis indicated that the group of patients with NMD presented a lower MEP/MIP ratio and \%MEP/\%MIP ratio compared to patients with PIBO and healthy individuals (Table 3).

On the other hand, in both NMD and PIBO patients, respiratory muscle function was correlated with MEP/MIP ratio; however, in healthy individuals, only MEP was correlated with MEP/MIP ratio. Moreover, in healthy individuals and patients with NMD, only \%MEP was correlated with \%MEP/\%MIP ratio and, in patients with $\mathrm{PIBO}$, only \%MIP was correlated with \%MEP/\%MIP (Table 4).

Table 2 Spirometric values of patients with chronic respiratory disease.

\begin{tabular}{l|c|c|c} 
& $\begin{array}{c}\text { NMD } \\
(\mathbf{n}=25)\end{array}$ & $\begin{array}{c}\text { PIBO } \\
(\mathbf{n}=27)\end{array}$ & p-value* \\
\hline $\mathrm{FEV}_{1}(\mathrm{l})$ & $1.6 \pm 0.5$ & $1.5 \pm 0.6$ & 0.338 \\
\hline $\mathrm{FEV}_{1}(\%)$ & $82.0 \pm 24.2$ & $65.5 \pm 20.1$ & 0.011 \\
\hline $\mathrm{FVC}(\mathrm{l})$ & $1.9 \pm 0.6$ & $2.3 \pm 0.9$ & 0.080 \\
\hline $\mathrm{FVC}(\%)$ & $79.1 \pm 28.8$ & $88.2 \pm 19.6$ & 0.071 \\
\hline $\mathrm{FEV}_{1} / \mathrm{FVC}$ & $87.6 \pm 7.7$ & $64.9 \pm 13.8$ & $<0.001$ \\
\hline $\mathrm{FEF}_{25-75}(\mathrm{l} / \mathrm{m})$ & $2.0 \pm 1.2$ & $1.0 \pm 0.7$ & $<0.001$ \\
\hline $\mathrm{FEF}_{25-75}(\%)$ & $76.6 \pm 30.7$ & $37.3 \pm 22.0$ & $<0.001$ \\
\hline $\mathrm{NMD}_{\mathrm{n}} \mathrm{neurom}$ & &
\end{tabular}

NMD: neuromuscular disease; PIBO: post-infectious bronchiolitis obliterans; FEV1: forced expiratory volume during the first second; FVC: forced vital capacity; FEF25-75: forced expiratory flow between the 25 and 75 percent of the forced vital capacity. Results are shown in absolute values (mean and standard deviation) and predictive values according to Knudson et al. *Independent sample Student's t-test was used.

Table 3 Respiratory muscle strength and the maximal expiratory pressure/maximal inspiratory pressure ratio of the study groups.

\begin{tabular}{|c|c|c|c|c|}
\hline & $\begin{array}{l}\text { Healthy } \\
(n=85)\end{array}$ & $\begin{array}{c}\text { NMD } \\
(n=25)\end{array}$ & $\begin{array}{c}\text { PIBO } \\
(n=27)\end{array}$ & p-value* \\
\hline $\operatorname{MIP}\left(\mathrm{cmH}_{2} \mathrm{O}\right)$ & $103.4 \pm 16.4$ & $56.8 \pm 19.3^{a . b}$ & $68.4 \pm 24.8^{a}$ & $<0.001$ \\
\hline MIP (\%) & $100.8 \pm 16.6$ & $54.9 \pm 18.1^{a}$ & $65.6 \pm 24.8^{a}$ & $<0.001$ \\
\hline $\operatorname{MEP}\left(\mathrm{cmH}_{2} \mathrm{O}\right)$ & $100.2 \pm 21.7$ & $47.2 \pm 18.3^{a . b}$ & $72.5 \pm 21.2^{\mathrm{a}}$ & $<0.001$ \\
\hline MEP (\%) & $75.2 \pm 17.0$ & $34.9 \pm 15.4^{a . b}$ & $52.6 \pm 19.2^{a}$ & $<0.001$ \\
\hline MEP/MIP ratio & $0.97 \pm 0.1$ & $0.87 \pm 0.3^{a . b}$ & $1.11 \pm 0.4$ & $0.017^{*}$ \\
\hline \%MEP/\%MIP ratio & $0.75 \pm 0.1$ & $0.64 \pm 0.2^{a . b}$ & $0.85 \pm 0.3$ & $0.004^{*}$ \\
\hline
\end{tabular}

NMD: neuromuscular disease; PIBO: post-infectious bronchiolitis obliterans; MIP: maximal inspiratory pressure; MEP: maximal expiratory pressure; \%: percentage of predictive values according to Contreras et al. a: statistical difference with healthy group ( $p<0.05)$; ${ }^{\text {b: }}$ statistical difference with PIBO group ( $p<0.05)$. *Kruskal-Wallis test. 
Correlation between MEP/MIP ratio and the age of individuals at the time of evaluation is presented in Figure 2. A negative correlation was observed between MEP/MIP and $\% \mathrm{MEP} / \% \mathrm{MIP}$ ratios with age only in patients with NMD (Figures $2 \mathrm{C}$ and $\mathrm{D}$ ).

Table 4 Correlation between the parameters of respiratory muscle strength and maximal expiratory pressure/maximal inspiratory pressure ratio.

\begin{tabular}{l|c|c|c} 
& $\begin{array}{c}\text { Healthy } \\
(\mathbf{n}=85)\end{array}$ & $\begin{array}{c}\text { NMD } \\
(\mathbf{n}=25)\end{array}$ & $\begin{array}{c}\text { PIBO } \\
(\mathbf{n}=27)\end{array}$ \\
\hline MIP $\left(\mathrm{cmH}_{2} \mathrm{O}\right)$ & -0.17 & $-0.44^{*}$ & $-0.40^{*}$ \\
\hline MIP $(\%)^{\mathrm{a}}$ & -0.10 & -0.24 & $-0.46^{*}$ \\
\hline MEP $\left(\mathrm{cmH}_{2} \mathrm{O}\right)$ & $0.67^{* * *}$ & $0.42^{*}$ & $0.43^{*}$ \\
\hline MEP $(\%)^{\mathrm{a}}$ & $0.69^{* * *}$ & $0.60^{* *}$ & 0.32 \\
\hline
\end{tabular}

NMD: neuromuscular disease; PIBO: post-infectious bronchiolitis obliterans; MIP: maximal inspiratory pressure; MEP: maximal expiratory pressure; \%: percentage of predictive values according to Contreras et al.; a: MIP and MEP expressed as relative value were correlated with \%MEP/\%MIP ratio; $*<0.05 ; * *<0.01 ; * * *<0.001$.

\section{DISCUSSION}

The measurement of the respiratory muscles is a frequent practice in the evaluation and follow-up of patients with NMD and PIBO. ${ }^{15,26}$ In this context, the present study aimed to analyze the pattern of respiratory muscles in children and adolescents with NMD and PIBO with the MIP/MEP ratio. Consequently, both weakness of respiratory muscles in both groups and significant differences in the pattern of inspiratory/expiratory muscular deterioration were observed. Thus, given that patients with NMD experienced substantial drops in the MEP/MIP ratio, patients with PIBO presented an increase in the magnitude of this variable.

These results are in accordance with those reported by Fregonezi et al., who observed significant differences in MEP/MIP index in patients with different types of neuromuscular diseases. In their study, a lower MEP/MIP ratio was observed in patients with myotonic dystrophy, which represents a more significant muscular weakness in this group of patients. ${ }^{21}$

In our study, the patients with NMD presented a $10.0 \%$ lower MEP/MIP ratio when compared to healthy individuals.

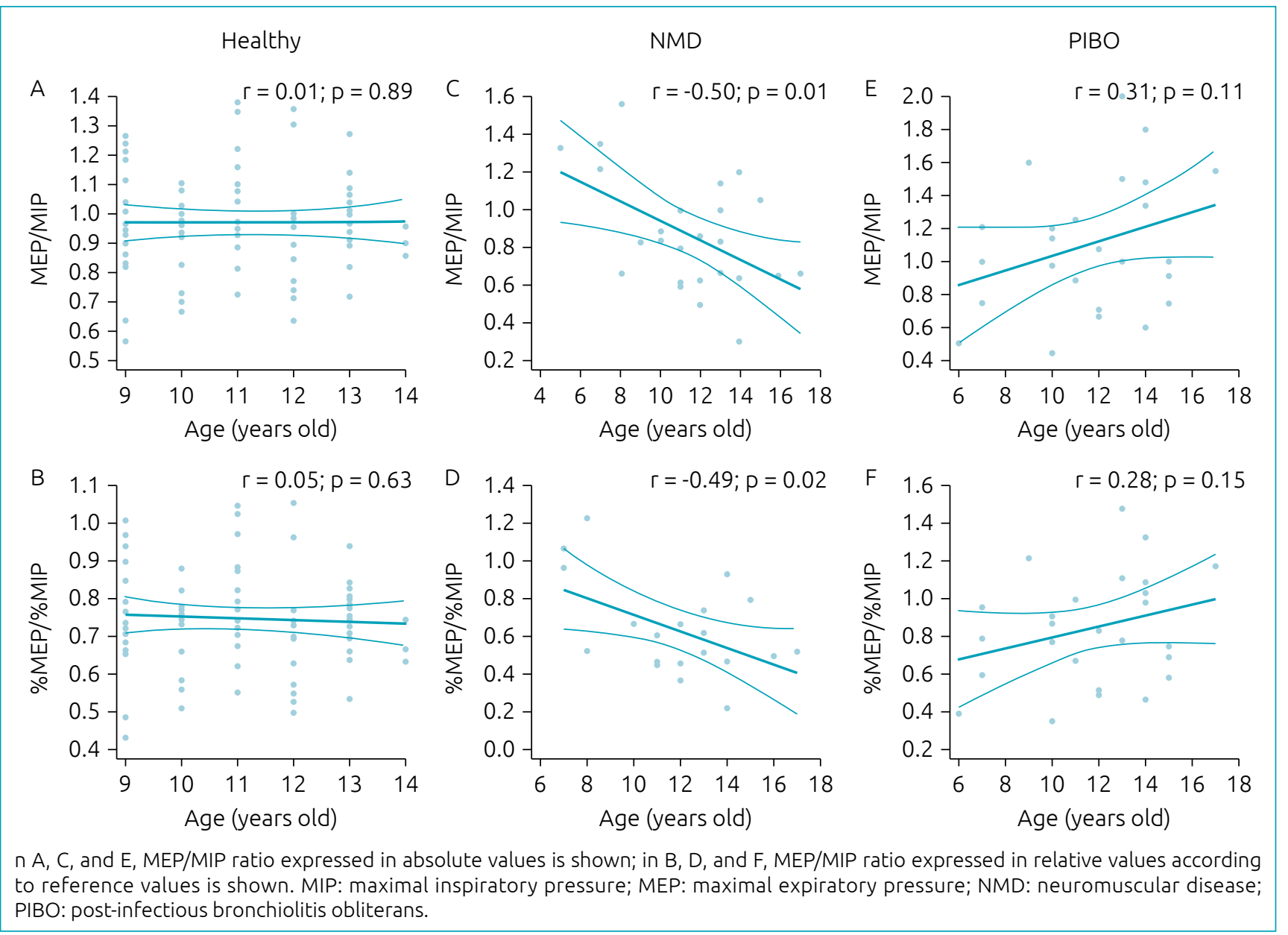

Figure 2 Correlation between maximal expiratory pressure/maximal inspiratory pressure ratio and age. 
Furthermore, most patients with NMD (52.0\%) had Duchenne Muscular Dystrophy (DMD). In this sense, several studies have revealed the existence of weakness in respiratory muscles in patients with different types of muscular dystrophy, which is associated to a significant deterioration of coughing capacity. ${ }^{27,28}$ This was confirmed by our results, in which the MEP/MIP ratio was mainly associated to the strength of expiratory muscles given the existence of a significant correlation between \%MEP/\%MIP with \%MEP, but not with the \%MIP (Table 4).

Moreover, the MEP/MIP ratio was inversely correlated with age only in patients with NMD. Previous studies agree with our findings by reporting the existence of a pattern of progressive respiratory muscle deterioration (mainly affecting the expiratory muscles) in patients with progressive NMD. ${ }^{4,29,30}$

Concerning patients with PIBO, several studies have revealed the existence of a secondary functional deterioration to pulmonary damage and a lower physical capacity. ${ }^{12,13,31}$ However, to date, no reports are showing respiratory muscle impairment in these patients. In our study, patients with PIBO experienced a 33.8\% lower level of inspiratory muscle strength, and $26.7 \%$ of all patients, a lower level of expiratory muscle strength when compared to the group with healthy individuals. The magnitude of deterioration is similar to that observed in other chronic pulmonary diseases. ${ }^{6,32,33}$

In addition, patients with PIBO experienced a higher MEP/MIP ratio compared to patients with NMD ( $<<0.05)$. Additionally, the variations in MEP/MIP ratio was mostly due to changes in the magnitude of the strength of inspiratory muscles. These results are in accordance with those from studies carried out in patients with other chronic pulmonary diseases, ${ }^{7,17,33-35}$ which have revealed the existence of weakness of inspiratory muscles associated to the induction of mechanisms of oxidative stress, apoptosis, and inspiratory muscular atrophy. ${ }^{1,236}$

Although there are no data regarding potential mechanisms underlying the functional deterioration observed in patients with PIBO, some studies observe a high level of oxidative stress in lung parenchyma, ${ }^{37-39}$ suggesting the possibility that inspiratory muscle weakness seen in these patients may be associated to oxidative mechanisms similar to those observed in patients with chronic obstructive pulmonary disease (COPD). ${ }^{1}$

To the best of our knowledge, the present study constitutes the first report that indicates the magnitude of respiratory muscle weakness in patients with PIBO, as well as the differences in the MEP/MIP ratio in children and adolescents with CRD when compared to healthy individuals. In this context, the recognition of a variable pattern of respiratory muscle weakness in patients with CRD has direct implications on rehabilitation, because such data allow focusing respiratory muscle training protocols on the muscle group that will be primarily affected according to the specific pattern of muscle deterioration of each patient. Despite this, determining whether muscle training focused on respiratory muscles is effective in recovering inspiratory/expiratory balance is needed, which should be explored in further research.

The present study has certain limitations to be discussed. Among them, the verification of exclusion criteria in the group of healthy individuals is highlight, which was performed with a checklist that was completed by parents, and no pulmonary function tests were conducted to identify the existence of any respiratory pathology in this group. Additionally, the \%MEP was less than the normal value $(75.2 \%)$. Therefore, it is not possible to rule out that the control group may be underrepresenting the healthy population, which could result in the presence of an eventual sampling bias.

On the other hand, patients with NMD presented different diagnoses, which impede to conclude for a specific type of NMD. Consequently, the existence of individual differences regarding the pattern of respiratory muscle weakness between different types of NMD could be feasible.

Finally, children and adolescents with NMD and PIBO presented weaknesses of respiratory muscle and experienced differences in the pattern of respiratory muscular weakness. Patients with NMD had a decrease in the MEP/MIP ratio associated with a lower strength of expiratory muscles and higher age of subjects, whereas in patients with PIBO there was an increase in the MEP/MIP ratio associated with a lower strength of inspiratory muscles.

\section{Funding}

This study did not receive any funding.

\section{Conflict of interests}

The authors declare there is no conflict of interests.

\section{REFERENCES}

1. Klimathianaki M, Vaporidi K, Georgopoulos D. Respiratory muscle dysfunction in COPD: from muscles to cell. Curr Drug Targets. 2011;12:478-88. https://doi. org/10.2174/138945011794751474
2. McKenzie DK, Butler JE, Gandevia SC. Respiratory muscle function and activation in chronic obstructive pulmonary disease. J Appl Physiol (1985). 2009;107:621-9. https://doi. org/10.1152/japplphysiol.00163.2009 
3. Buu MC. Respiratory complications, management and treatments for neuromuscular disease in children. Curr Opin Pediatr. 2017;29:326-33. https://doi.org/10.1097/ mop.0000000000000498

4. Neve V, Cuisset JM, Edme JL, Carpentier A, Howsam M, Leclerc O, et al. Sniff nasal inspiratory pressure in the longitudinal assessment of young Duchenne muscular dystrophy children. Eur Respir J. 2013;42:671-80. https:// doi.org/10.1183/09031936.00127712

5. Meier T, Rummey C, Leinonen M, Spagnolo P, Mayer $\mathrm{OH}$, Buyse GM. Characterization of pulmonary function in 10-18 year old patients with Duchenne muscular dystrophy. Neuromuscul Disord. 2017;27:307-14. https:// doi.org/10.1016/j.nmd.2016.12.014

6. Dassios T, Katelari A, Doudounakis S, Dimitriou G. Aerobic exercise and respiratory muscle strength in patients with cystic fibrosis. Respir Med. 2013;107:684-90. https://doi. org/10.1016/j.rmed.2013.01.016

7. Dassios TG, Katelari A, Doudounakis S, Dimitriou G. Chronic Pseudomonas aeruginosa infection and respiratory muscle impairment in cystic fibrosis. Respir Care. 2014;59:363-70. https://doi.org/10.4187/respcare.02549

8. Gozal D. Pulmonary manifestations of neuromuscular disease with special reference to Duchenne muscular dystrophy and spinal muscular atrophy. Pediatr Pulmonol. 2000;29:141-50. https://doi.org/10.1002/(sici)10990496(200002)29:2\%3C141::aid-ppul9\%3E3.0.co;2-y

9. Anderson VB, McKenzie JA, Seton C, Fitzgerald DA, Webster $\mathrm{RI}$, North KN, et al. Sniff nasal inspiratory pressure and sleep disordered breathing in childhood neuromuscular disorders. Neuromuscul Disord. 2012;22:528-33. https:// doi.org/10.1016/j.nmd.2012.02.002

10. Vega-Briceño L, Zenteno D. Clinical guide for diagnosis and care of children and adolescents with post-infectious bronchiolitis obliterans, 2009. Rev Chil Enf Respir. 2009;25:141-63.

11. Castro-Rodriguez JA, Daszenies C, Garcia M, Meyer R, Gonzales R. Adenovirus pneumonia in infants and factors for developing bronchiolitis obliterans: a 5-year follow-up. Pediatr Pulmonol. 2006;41:947-53. https://doi.org/10.1002/ppul.20472

12. Rodríguez I, Heríquez S, Vásquez P, Zenteno D. Six minute walking test and pulmonary function in patients with post infectious bronchiolitis obliterans. Rev Chil Enferm Respir. 2014;30:68-74. http://dx.doi.org/10.4067/S071773482014000200002

13. Frohlich LF, Vieira PJ, Teixeira PJ, Silva FA, Ribeiro JP, Berton DC. Exercise capacity in adolescent and adult patients with post infectious bronchiolitis obliterans. Pediatr Pulmonol. 2014;49:911-8. https://doi.org/10.1002/ppul.22929

14. American Thoracic Society/European Respiratory Society. ATS/ERS statement on respiratory muscle testing. Am J Respir Crit Care Med. 2002;166:518-624. https://doi. org/10.1164/rccm.166.4.518

15. Torres-Castro R, Zenteno D, Rodríguez-Núñez I, Villarroel G, Alvarez C, Gatica D,et al. Pulmonary rehabilitation guidelines in children with chronic respiratory diseases: 2016 update. Neumol Pediátr. 2016;11:114-31.

16. Kim EY, Lee JW, Suh MR, Choi WA, Kang SW, Oh HJ. Correlation of serum creatine kinase level with pulmonary function in duchenne muscular dystrophy. Ann Rehabil Med. 2017;41:306-12. https://doi.org/10.5535/arm.2017.41.2.306

17. Arikan H, Yatar I, Calik-Kutukcu E, Aribas Z, Saglam M, VardarYagli N, et al. A comparison of respiratory and peripheral muscle strength, functional exercise capacity, activities of daily living and physical fitness in patients with cystic fibrosis and healthy subjects. Res Dev Disabil. 2015;45-46:147-56. https://doi.org/10.1016/j.ridd.2015.07.020

18. Rodríguez I. Reliability of pulmonary function tests in healthy adolescents. Rev Chil Enferm Respir. 2015;31:86-93. http:// dx.doi.org/10.4067/S0717-73482015000200003

19. Rodrigues A, Silva ML, Berton DC, Cipriano G Jr, Pitta F, O'Donnell DE, et al. Maximal inspiratory pressure: does the choice of reference values actually matter? Chest. 2017;152:32-9. https://doi.org/10.1016/j.chest.2016.11.045

20. Koo P, Oyieng'o DO, Gartman EJ, Sethi JM, Eaton CB, McCool FD. The maximal expiratory-to-inspiratory pressure ratio and supine vital capacity as screening tests for diaphragm dysfunction. Lung. 2017;195:29-35. https://doi.org/10.1007/ s00408-016-9959-z

21. Fregonezi G, Azevedo IG, Resqueti VR, Andrade AD, Gualdi LP, Aliverti A, et al. Muscle impairment in neuromuscular disease using an expiratory/inspiratory pressure ratio. Respir Саге. 2015;60:533-9. https://doi.org/10.4187/respcare.03367

22. Miller MR, Hankinson J, Brusasco V, Burgos F, Casaburi R, Coates A, et al. Standardisation of spirometry. Eur Respir J. 2005;26:31938. https://doi.org/10.1183/09031936.05.00034805

23. Knudson RJ, Lebowitz MD, Holberg CJ, Burrows B. Changes in the normal maximal expiratory flow-volume curve with growth and aging. Am Rev Respir Dis. 1983;127:725-34. https://doi.org/10.1164/arrd.1983.127.6.725

24. Larson JL, Covey MK, Vitalo CA, Alex CG, Patel M, Kim MJ. Maximal inspiratory pressure. Learning effect and test-retest reliability in patients with chronic obstructive pulmonary disease. Chest. 1993;104:448-53. https://doi.org/10.1378/ chest.104.2.448

25. Dimitriadis Z, Kapreli E, Konstantinidou I, Oldham J, Strimpakos N. Test/retest reliability of maximum mouth pressure measurements with the MicroRPM in healthy volunteers. Respir Care. 2011;56:776-82. https://doi. org/10.4187/respcare.00783

26. Schoser B, Fong E, Geberhiwot T, Hughes D, Kissel JT, Madathil SC, et al. Maximum inspiratory pressure as a clinically meaningful trial endpoint for neuromuscular diseases: a comprehensive review of the literature. Orphanet J Rare Dis. 2017;12:52. https://doi.org/10.1186/s13023-017-0598-0

27. Park JH, Kang SW, Lee SC, Choi WA, Kim DH. How respiratory muscle strength correlates with cough capacity in patients with respiratory muscle weakness. Yonsei Med J. 2010;51:392-7. https://doi.org/10.3349/ymj.2010.51.3.392

28. Kang SW, Kang YS, Sohn HS, Park JH, Moon JH. Respiratory muscle strength and cough capacity in patients with Duchenne muscular dystrophy. Yonsei Med J. 2006;47:18490. https://doi.org/10.3349/ymj.2006.47.2.184

29. Khirani S, Ramirez A, Aubertin G, Boulé M, Chemouny C, Forin $\mathrm{V}$, et al. Respiratory muscle decline in Duchenne muscular dystrophy. Pediatr Pulmonol. 2014;49:473-81. https://doi. org/10.1002/ppul.22847 
30. Khirani S, Colella M, Caldarelli V, Aubertin G, Boulé M, Forin $V$, et al. Longitudinal course of lung function and respiratory muscle strength in spinal muscular atrophy type 2 and 3 . Eur J Paediatr Neurol. 2013;17:552-60. https://doi.org/10.1016/j. ejpn.2013.04.004

31. Mattiello R, Sarria EE, Stein R, Fischer GB, Mocelin HT, Barreto SS, et al. Functional capacity assessment in children and adolescents with post-infectious bronchiolitis obliterans. J Pediatr (Rio J). 2008;84:337-43. https://doi.org/10.2223/ jped.1807

32. Dassios TG, Katelari A, Doudounakis S, Dimitriou G. Chronicpseudomonas aeruginosa infection and respiratory muscle impairment in cystic fibrosis. Respir Care. 2014;59:36370. https://doi.org/10.4187/respcare.02549

33. Heinzmann-Filho JP, Vendrusculo FM, Woszezenki CT, Piva TC, Santos AN, Barcellos AB, et al. Inspiratory muscle function in asthmatic and healthy subjects: influence of age, nutrition and physical activity. J Asthma. 2016;53:893-9. https://doi. org/10.3109/02770903.2016.1165698

34. Marcelino AM, Cunha DA, Cunha RA, Silva HJ. Respiratory muscle strength in asthmatic children. Int Arch Otorhinolaryngol. 2012;16:492-6. https://doi.org/10.7162/ s1809-97772012000400010
35. Ambrosino N, Venturelli E, Blasio F, Paggiaro P, Pasqua F, Vitacca $M$, et al. A prospective multicentric study of pulmonary rehabilitation in patients with chronic obstructive pulmonary disease and different clinical phenotypes. Respiration. 2015;89:141-7. https://doi.org/10.1159/000371471

36. Rodríguez I, Arriagada R, Fuentes C, Zenteno D. Pathophysiology of respiratory rehabilitation in cystic fibrosis. Neumol Pediátr. 2012;7:51-7.

37. Madill J, Aghdassi E, Arendt B, Hartman-Craven B, Gutierrez C, Chow CW, et al. Lung transplantation: does oxidative stress contribute to the development of bronchiolitis obliterans syndrome? Transplant Rev (Orlando). 2009;23:103-10. https://doi.org/10.1016/j.trre.2009.01.003

38. Behr J, Maier K, Braun B, Schwaiblmair M, Vogelmeier C. Evidence for oxidative stress in bronchiolitis obliterans syndrome after lung and heart-lung transplantation. The Munich Lung Transplant Group. Transplantation. 2000;69:1856-60. https://doi.org/10.1097/00007890200005150-00020

39. Mallol J, Aguirre V, Espinosa V. Increased oxidative stress in children with post infectious Bronchiolitis Obliterans. Allergol Immunopathol (Madr). 2011;39:253-8. https://doi. org/10.1016/j.aller.2010.09.003 